\title{
Livelihood strategies of smallholder coffee farmers: case study in Simalungun, North Sumatera
}

\author{
Diany Faila Sophia Hartatri ${ }^{1 *}$ and Jeffrey Neilson ${ }^{2}$ \\ ${ }^{1}$ Indonesian Coffee and Cocoa Research Institution, J1 PB Sudirman, Jember, East Java, Indonesia \\ ${ }^{2}$ Sydney University
}

\begin{abstract}
The majority of coffee in Simalungun is produced by smallholder coffee farmers who have several issues, including limited working capital, access to knowledge, technology and market information. These issues have impacted on low productivity that further has caused the low income obtained from coffee farm. The aim of this research is to understand the livelihood strategies applied by smallholder coffee farmers and to analyze the contribution of coffee to the household farmers' income. A household survey has been carried out in 2018. The survey was conducted in Silimakuta, Dolok Silau, Purba, Pematang Silimakuta, Dolok Silau, and Pematang Purba sub districts. There were 200 smallholder coffee farmers interviewed in this research. The research showed that the majority of coffee farmers applied diversification livelihood strategies. The smallholder coffee farmers are also maintaining diverse and highly intensive horticulture production, such as citrus, potatoes, tomatoes, cabbage and chili. The research results indicate that coffee consist only part of the smallholder coffee farmers livelihood. However, coffee plays important contribution as source of smallholder coffee farmers' income, with average coffee contribution to smallholder household farmers accounted for $42.30 \%$ to household farmers' income. The income gained from coffee is generally spent to meet staple food needs, particularly to buy rice.
\end{abstract}

\section{Introduction}

Indonesia has abundant natural resources, including agricultural, fisheries, and forestry. Agriculture is key sector for Indonesian economy. Most of the agriculture sector is cultivated by smallholder farmers. These natural resources play crucial role as the important sources of national income and for millions of smallholders who depend on these sectors.

In 2020, shares of Gross Domestic Product (GDP) of estate crops to total GDP was increasing (see Table 1). This caused by the increasing of several commodities' performances, particularly oil palm, rubber and coffee. Therefore, coffee plays important role for not only national income but also millions of households, including smallholder coffee farmers across Indonesia. There are 743,408 smallholder coffee farmers grow coffee

* Corresponding author: il three@yahoo.com 
in Indonesia [1]. Moreover, Indonesia is an important coffee producing country, as Indonesia is the fourth biggest coffee producing country after Brazil, Vietnam and Colombia with Indonesian contribution is about $6.9 \%$ of total world coffee production [2].

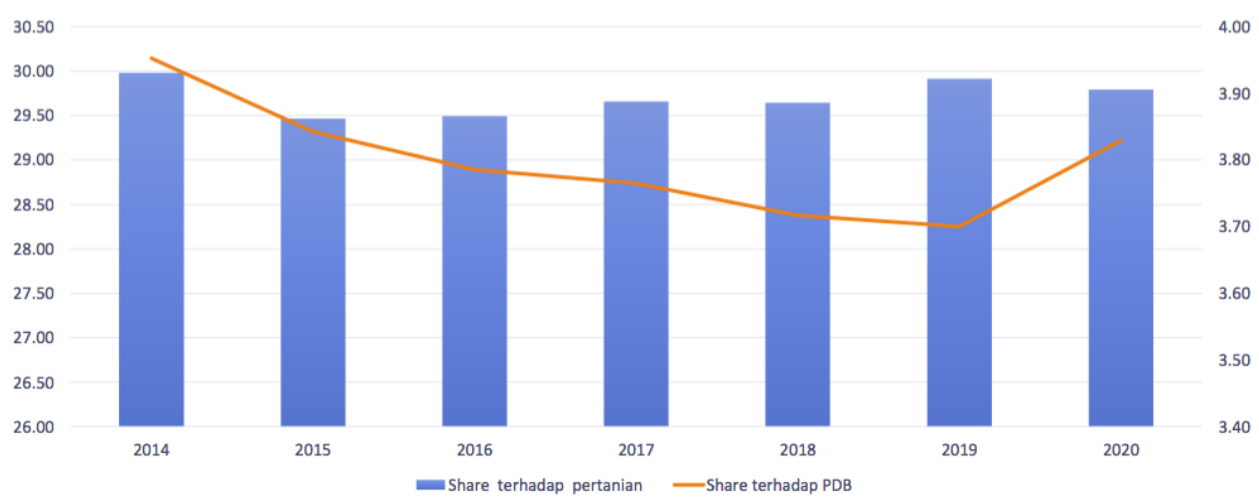

Fig 1. Shares of estate crop to GDP of agricultural sector and Indonesian GDP

Table 1. World coffee production

\begin{tabular}{|c|c|c|c|c|c|c|c|}
\hline Country & & $\mathbf{2 0 1 4} / \mathbf{1 5}$ & $\mathbf{2 0 1 5} / \mathbf{1 6}$ & $\mathbf{2 0 1 6} / \mathbf{1 7}$ & $\mathbf{2 0 1 7} / \mathbf{1 8}$ & $\mathbf{2 0 1 8} / \mathbf{1 9}$ & $\mathbf{2 0 1 9} / \mathbf{2 0}$ \\
\hline Brazil & (A/R) & 53,305 & 52,871 & 56,788 & 52,740 & 62,925 & 58,211 \\
\hline Viet Nam & (R/A) & 26,500 & 28,737 & 25,540 & 27,888 & 31,174 & 30,487 \\
\hline Colombia & (A) & 13,333 & 14,009 & 14,634 & 13,824 & 13,858 & 14,100 \\
\hline Indonesia & (R/A) & 10,946 & 12,585 & 11,541 & 10,852 & 9,418 & 11,433 \\
\hline Ethiopia & (A) & 6,575 & 6,714 & 7,297 & 7,454 & 7,776 & 7,343 \\
\hline Honduras & (A) & 5,268 & 5,786 & 7,457 & 7,560 & 7,328 & 5,931 \\
\hline India & (R/A) & 5,450 & 5,830 & 6,161 & 5,813 & 5,302 & 4,988 \\
\hline Uganda & (R/A) & 3,744 & 3,650 & 4,962 & 4,597 & 4,704 & 5,509 \\
\hline Mexico & (A/R) & 3,636 & 2,772 & 3,635 & 4,485 & 4,351 & 3,985 \\
\hline Peru & (A) & 2,883 & 3,304 & 4,223 & 4,279 & 4,263 & 3,836 \\
\hline Total & & $\mathbf{1 4 9 , 7 5 3}$ & $\mathbf{1 5 3 , 9 8 8}$ & $\mathbf{1 5 9 , 9 1 6}$ & $\mathbf{1 5 8 , 0 7 4}$ & $\mathbf{1 7 0 , 9 3 7}$ & $\mathbf{1 6 5 , 0 5 3}$ \\
\hline
\end{tabular}

Source : [2]

Indonesia has been a leading coffee producing country for centuries [3]. The main types of coffee produced by Indonesia are Robusta, and Arabica, about $75 \%$ and $25 \%$ of the total coffee production, respectively. The main market of Robusta coffee is domestic market, meanwhile the majority of Arabica is exported to several countries, particularly in developed countries, such as European countries, the USA, Japan and Australia. The increasing demand of specialty coffee in the world market has increased the demand of Indonesian Arabica coffee. Recently, Indonesia is well known as the one of biggest specialty coffee producing country. The main specialty coffee producing areas are Northern Sumatera (North Sumatera and Aceh), Southern Sulawesi (Toraja and Enrekang), East Nusa Tenggara (Flores), Kintamani (Bali), Kayumas, Dampit and Blawan (East Java) and Bandung, Garut, Sumedang (West Java). In these coffee producing areas, the majority of coffee is cultivated by smallholder farmers.

In domestic market, the demand of coffee, including specialty coffee is also increasing. This paralleled with the increasing number of café and coffee shop, particularly in big cities, such as Jakarta, Surabaya, Medan and Yogyakarta. Therefore, this circumstance has increased the opportunity of smallholder coffee farmers to upgrade the coffee quality and to be linked with a higher price value chain. Further, the smallholder coffee farmers have a higher opportunity to gain higher income and improve their livelihoods. 
As mentioned above, North Sumatera is a key Arabica coffee production area in Indonesia. Simalungun district is one of the coffee production areas in North Sumatera. Coffee produced in this area is well known as high quality coffee that mostly exported to US and other consuming countries, such as European, Japan and Australia. Similar with other coffee producing area, coffee in this area is also grown by smallholder coffee farmers. These smallholder coffee farmers have different livelihood strategies to fulfil their daily needs. The aim of this research is to understand the livelihood strategies applied by smallholder coffee farmers in Simalungun, North Sumatera. Also, to understand the contribution of coffee to household farmers' income.

\section{Materials and methods}

The study applied case study approach as this research aim is to understand the livelihood of coffee farmers in specific area. The research was conducted in Simalungun, North Sumatera, which focused on five sub districts, namely Silimakuta, Dolok Silau, Purba, Pematang Silimakuta, Dolok Silau, and Pematang Purba.

This research applied a case study approach as this research was only focused on household coffee farmers in Simalungun, North Sumatera. The data collection applied household survey method that has been conducted in 2018. There were 200 smallholder coffee farmers who were the member of CUM Talenta interviewed by applying structured questionnaire with opened and closed questions. Then, the data was inputed in Excel and analysed by descriptive method. In addition, the researcher also conducted field observation and in-depth interview with several key person to understand the farm practice and livelihood activity portofolios.

\section{Results and discussion}

Indonesia has been known as one of the specialty coffee producers. Simalungun is one of specialty coffee producing areas in Indonesia, that in world market the Simalungun coffee is marketed as Sumateran coffee. This coffee has supplied the largest café in the world. However, in the production of coffee sector, Indonesian coffee, including Simalungun faces several challenges, such as the low coffee productivity and low coffee quality, particularly for Robusta coffee. The average coffee productivity in Indonesia was $810 \mathrm{~kg} / \mathrm{ha} / \mathrm{year}$ [1]. However, this productivity is about $30 \%$ of the potential productivity of high quality of coffee, which can reach about $2,500 \mathrm{~kg} / \mathrm{ha} /$ year. This is mainly because the majority of coffee farms in Indonesia is managed by smallholder coffee farmers, that involves about 2 million household farmers [1]. These smallholder coffee farmers facing several difficulties in accessing knowledge, technology and market information. Moreover, the limitation on working capital to buy agricultural inputs, such as fertilizers and chemicals has led the low productivity of coffee. This indicates that coffee is not organized as a profit business [4].

In the context of agricultural sector, livelihood strategy in order to reduce poverty is not a new approach. Mostly the Indonesian household farmers in rural areas depend on diversity of activities and sources of income among crops, livestock and even nonagricultural sector that can contribute to improve their family's well-being. The involvement of household farmers in various activities is mainly to meet their needs that contribute to a collective livelihood $[5,6]$. Involvement in the various household activities means that the households develop their social networks of community. A livelihood "comprises the capabilities, assets (stores, resources, claims and access) and activities required for a means of living" [6]. This definition has been modified and applied by several scholars [7-10]. Capabilities are the ability of human being to obtain their potential 
using their social, economic and individual characteristics. Capabilities are influenced by individual characteristic and household livelihood strategies.

The challenges faced by the smallholder coffee farmers has led the intervention on coffee value chain conducted by several stakeholders, such as government, NGOs and private sectors, including roasters and exporters. The value chain intervention is not only conducted in Indonesia, but also in other coffee producing countries.

The main aim of coffee value chain intervention is for increasing the farm-gate price and to increase farmers' livelihoods. Since 2001, local government in Bali collaborated with ICCRI conducted "village-level industrialization" in Kintamani. This intervention involved Subak Abian as Unit Pengolahan Hasil (UPH). Then, the intervention provided training in coffee quality upgrading and several coffee producing machines, such as pulper, washer and huller [11]. Then, this intervention has been replicated in other coffee producing areas, such as Flores, Bondowoso, and Semendo. Meanwhile, in Enrekang, South Sulawesi the intervention was conducted to establish a relationship between a roaster company and cooperative. The interventions have presented the opportunities of smallholder farmers to obtain higher access to knowledge, technologies, finance, and infrastructure. Furthermore, the cooperative also has more opportunity to produce higher quality coffee and to establish direct linkages with specialty coffee roasters [11].

\subsection{Farmers characteristics}

The age of farmers will influence on coffee sustainability. Aging of coffee farmers is one of the issues faced by Indonesian coffee sector. In addition, youth generation prefer to have carrier in non-agricultural sector. This mainly because there is assumption that working in agricultural sector requires physical hard work, dirty and cannot make prosperous. Therefore, in order to attract youth to work on agricultural sector, nowadays mechanization is considered as one of crucial efforts.

The household farmer survey revealed that the average age of coffee farmers in Simalungun was 50.6-year-old. This age is categorized as productive age. This productive age will influence on productivity. In addition, the productivity is also influenced by other factors, such as education of farmers and experiences of farmers on coffee farming. The survey results showed that the majority of education level of coffee farmers is high school, accounted for $46.12 \%$, followed by junior high school, elementary school, university and no school, accounted for $24.27 \%, 17.96 \%, 7.28 \%$, and $4.37 \%$ respectively. Meanwhile, the average farmers' experiences on coffee farming was 11.62 years. Owning more experiences on cocoa farming will influence farmers on decision making. Further, this will influence on coffee production [12].

\subsection{Land holding, coffee farming system and coffee productivity}

The average land holding of coffee farmers in Indonesia is tend to low, which is 0.8 ha Further, this will influence the farming management. Also, this will hinder the smallholder farmers to expand their livelihoods. According to the survey, the average agricultural land managed by farmers in Simalungun is 1.39 ha per household farmers. However, this agricultural land not only consist of coffee crop, but also horticultural crops, such as tomatoes, chilli and potatoes. According to the household farmer survey, the land holding of coffee is only 0.39 ha per household. Therefore, this coffee land ownership is lower than that of the national coffee farm. Land holding plays important role and has significant impact on coffee production and household farmers' income [13]. The household with a large coffee farm could able to produce higher volume of coffee [14-15] that enable the household farmer to secure their livelihood. 
As mentioned above, the smallholder farmers applied diversification cropping system, this indicates that the farmers in Simalungun are not merely depend on coffee as their household income. Field observation revealed that in Simalungun, the farmers grow coffee with horticulture crops. Diversification can be meant as integrated farming system which is generally conducted by Indonesian smallholder farmers to increase production and diversify several crops in an agricultural land [16]. In the beginning, the purpose of smallholder farmers applying diversification cropping system is to fulfill the basic needs of household farmer, but then developed for fulfilling market demand and increasing household's income. However, the application of diversification cropping system should be conducted rationally and dynamic by considering environmental and market demand in order to provide maximum benefits in increasing the land production and income of farmers [17].

Coffee production and productivity is influenced by several factors. One of the factors is input, including fertilizer, pesticide and labour. According to the survey, the majority of farmers using chemical agricultural inputs, such as fertilizers and pesticides in their coffee farm. However, generally farmers stated that these agricultural inputs are mainly aimed for horticulture crops. Further, this has led the low coffee productivity. Household survey revealed that the average coffee productivity was $597.86 \mathrm{~kg} / \mathrm{ha} /$ year. This productivity is lower than the national productivity and only about $25 \%$ of the potential production. This is influenced by several factors, such as the low population of coffee farmers as the coffee is cultivated with horticulture crops; the farmers are not using shade trees in the coffee plantation and the farmers are not using superior coffee seedlings. However, this productivity is higher than that of the coffee productivity in other coffee producing areas, such as Flores and Toraja [3].

The low coffee productivity in Flores and Toraja is caused by the far distance of their coffee farms from farmers' house. Further, this has led the farmers rarely conduct coffee farm maintenance activities, such as pruning, fertilizing, weeding and controlling pest and diseases. Moreover, this has been exacerbated with the traditional planting system applied by farmers as the minimum working capital for buying inputs. The working capital is significantly impacted on coffee productivity [13]. Therefore, the low production of coffee in the farmers' level is mainly influenced by the minimum working capital provided by the coffee farms.

\subsection{Farmers' access to extension services}

The access of farmers to knowledge, technology and market information will influence on coffee productivity and farm-gate price of coffee. However, the research results showed that farmers in Simalungun have limited access to knowledge, technology and market information. There were only $10.5 \%$ of the respondents who had access to extension services. The extension services mainly provided by NGOs and coffee buyers, meanwhile, there was no extension services provided by the government. This indicates the low support and facilitation of the local government to the coffee farmers in Simalungun.

According to the in-depth interview, the local government paid more attention on horticulture crops compared to coffee. The topic of extension services that received by farmers were Good Agricultural Practices of coffee cultivation, including pruning, fertilizing, and pest and diseases control. In addition, farmers also received topic on postharvest handling and coffee cupping test. Therefore, in order to increase the coffee productivity in Simalungun area, the role of government is required. The facilitation provided by the local government is expected not only on technical aspect but also in strengthening farmers organization. Further, this will strengthen the bargaining position of farmers on marketing activities, hence, the income of coffee farmers will increase. 


\subsection{Farmers' access to financial}

Indonesian coffee farmers are mainly involved in the traditional trade networks who generally linked with village-level collectors. As mentioned above that cultivating coffee crops requires work capital for purchasing agricultural inputs, such as fertilizers, pesticides, herbicides and hired labour. In addition, in the producing green bean coffee, it also requires additional funds, mainly for pulping, washing, drying and hulling the coffee bean. However, the majority of smallholder coffee farmers have limited working capital. Generally, the village-level collectors have performed crucial social and economic functions as the collectors offering credit to smallholder farmers, product marketing and merchandising the household farmers' necessities, such as staple food and sugar [19]. However, only part of smallholder farmers is willing to take credit to support their farming activities and to fulfil their needs. As part of smallholder farmers don't have a collateral, such as land certificate and proof of motorized vehicle ownership.

Farmers' access to credit positively affected choices of diversified livelihood strategies [20]. The research result shows that $43.5 \%$ of the coffee farmers in Simalungun have access to credit. however, there was no farmer who take credit from commercial bank. Tis mainly because the commercial banks require collateral for credit. Therefore, the farmers prefered to take credit from cooperative, called CUM Talenta, village collectors, neighbour, family and friends.

\subsection{Marketing of coffee and income of coffee at farmers' level}

In Indonesia, there are several coffee forms sold by smallholder farmers. Generally, robusta coffee farmers sell coffee in green bean form. Meanwhile in several arabica coffee producing areas, particularly in Sumatera and Sulawesi, the coffee farmers sell coffee in wet parchment coffee. Steps for producing wet parchment coffee is pulping, fermentation, washing and drying coffee parchment approximately one day, until the moisture content about $30 \%$. Coffee farmers in East Java, Bali and Flores are mainly produced dry parchment or green beans form that produced into full-washed processing method. The processing of full-washed coffee is pulping, fermentation, washing, drying coffee parchment until moisture content reach about $12 \%$, then hulling into green beans. Therefore, producing wet parchment requires a simpler step and shorter time.

Considering the limitation of labour and working capital. This may more beneficial for smallholder farmers. Moreover, this support farmers to gain income sooner. In these coffee producing areas where UPH is exist, the majority smallholder coffee farmers sell coffee into red cherries coffee form. Selling coffee into this form requires simplest steps, however the added value of coffee is none. This may lead low price in the farmers' level. The results indicate that the majority of coffee farmers in Simalungun produced wet parchment coffee, accounted for $97.5 \%$, meanwhile only $2.5 \%$ farmers who sold red cherries coffee. Further, this will influence on the farm-gate price as the higher added value.

In addition, the farm-gate price is also influenced by marketing chain of coffee. The more complex marketing chain will cause the low farm-gate price. In contrast, the simpler marketing chain will increase the farm-gate price. Generally, Indonesian coffee involves 4 -5 hands before coffee is received by consumers. In order to reduce the complexity of marketing chain, there was an intervention in several coffee producing areas, including Simalungun. The intervention known as "relationship coffee". This intervention aims to linkage farmers' cooperative, namely CUM Talenta with a roaster company. Throughout this intervention was expecting to provide more benefits for both parties. The benefits for 
smallholder farmers are higher access to knowledge, technology and market information, also higher farm-gate price. Meanwhile, the benefits for buyer is certainty to obtain high quality of coffee. According to the survey, coffee produced by smallholder farmers in Simalungun was mainly sold to village collector, local trader in market and cooperative, namely CUM Talenta, accounted for 58\%, 5\% and 37\% respectively. Then, the coffee was sold to trader and exporter or roaster companies. This indicates the complex value chain in the coffee sector in Simalungun.

Research results showed that unfortunately, the majority of coffee farmer organization not existed. Meanwhile, organization of farmers plays significant roles in supporting farmers. For example, farmer organization in East Java, West Java, Bali and Flores plays important role in transfer knowledge, technology and market information, particularly through routine monthly meeting held by farmer groups. In addition, farmer group also contributes on organizing post-harvest handling and coffee marketing activities. By conducting collective coffee processing and coffee marketing at farmer group will increase the price as the higher quality of coffee and higher bargaining position of farmers. Because in Simalungun district the farmer organizations not existed, this has led the farmers sold coffee individually. This also a factor that will influence on farm-gate price and farmers' income.

In terms of income, the household farmers' income is alongside influenced by productivity is also influenced by farm-gate price. In June, 2018 when the household farmers survey was conducted in Simalungun, the coffee price in the global market was USD \$ 2.68 equivalent to IDR 38,332/kg [2]. Meanwhile, the household farmers survey result showed that the average farm-gate price of coffee was almost double of global coffee price, which was IDR 62,490 per $\mathrm{kg}$ green beans equivalent. Therefore, the farm-gate price of coffee in Simalungun was high. The high price of coffee received by smallholder farmers was caused by the high quality of coffee produced by farmers. This mainly because the smallholder farmers have conducted standard post-harvest handling, including pulping, fermentation, washing and drying the coffee. Further, this has resulted the high cup test quality of coffee. In the global market, coffee produced by farmers in Simalungun is marketed as "Sumateran" coffee, and has been well-known as specialty coffee which has high market demand. Even, biggest coffee shop company "Starbucks" selling "Sumateran" coffee as single origin coffee. Therefore, the cup quality of "Sumateran coffee" has been recognized as high quality of coffee.

As mentioned above, the majority of coffee farmers in Simalungun sold coffee into raw material, which was wet parchment form. This coffee sold form has hindered farmers to obtain added value of downstream coffee products, both intermediate product, namely roasted coffee beans and final products, for example ground coffee, instan coffee and ready to drink coffee. According to field observation and interview, this was because there was no local government program to support village level industrialization, by providing downstream equipment, such as coffee sorting machine, roaster, grinder and packaging machine. Meanwhile, the limitation working capital owned by smallholder farmers has limited farmers to invest in the downstream coffee small-scale industry. Therefore, coffee stakeholders' attention on downstream coffee sector is required to support the coffee production sustainability in Simalungun.

As mentioned above, smallholder farmers in Simalungun grow various crops. There were $61.5 \%$ of the respondents were also grown other crops, particularly horticulture, such as chilli, tomatoes, potatoes, cabbage, onion and citrus. In addition, the household farmers were also growing staple crop to fulfil their basic needs. Several household farmers also gained income from non-agricultural sector, such as trading and construction worker. This showed that farmers applied diversification livelihood strategy [16]. The diverse livelihoods have caused the household farmers cannot focus on particular commodity, both on human 
resources and working capital. Further, this has impacted on the low productivity and low income. Moreover, the number of farmers who growing staple crops was only $19.5 \%$. Therefore, the majority of farmers purchase rice to meet their food needs. According to the interview, the farmers said that their grow coffee is mainly for fulfilling their basic need to purchase staple food. This indicates that coffee was not farmers' main crop. In addition, this also indicates that farmers do not believe that coffee could make them prosperous.

The research shows that the average income of smallholder coffee farmers in Simalungun was IDR 40,779,817/year/household. Meanwhile, the average income from coffee gained by smallholder farmers was IDR 26,007,269/year/household. According to the survey, coffee contributes about $42.30 \%$ to the household farmers' income. In the future, several efforts for supporting smallholder coffee farmers in Simalungun are required, thus coffee production in Simalungun is sustainable.

\section{Conclusion}

Coffee farmers face several challenges, such as limited land holding, working capital, access to extension services, access to financial. This has forced farmers to applied diversification livelihood strategies, that can be seen from various crops grown by smallholder farmers and working in non-agricultural sector. Coffee is one of the commodities that grown by smallholder farmers in Simalungun district, North Sumatera. Thus, coffee is only a part of smallholders' livelihood. Smallholder coffee farmers in Simalungun produced high quality coffee and marketed as specialty coffee products. However, the smallholder farmers merely produce green beans as raw material. This has impacted on the income of household farmers. Thus, providing training on downstream product process and processing equipment, such as sortation machine, roaster and grinder machine will also increase farm-gate coffee price and household farmers' income.

In addition, development of direct relationship with buyers of specialty coffee will also increase the farm-gate price of coffee in Simalungun. Moreover, increasing farm-gate price and farmers' income can also be conducted through establishing direct relationship with buyers as this will also increase the access of smallholder farmers to market information, knowledge and technology. Therefore, this suggests a need the role of formal institutions supporting farmers and farmer organisations as a vehicle for promoting direct relationship with buyers, both exporter and roaster companies.

\section{References}

1. Directorate General of Estate Crop. Jakarta (2020).

2. International Coffee Organization (2020).

3. Neilson, J., Diany, F.S.H., Yayoi, F.L, Coffee-based livelihoods in Flores, Indonesia. Final report for ACIAR SMAR/2007/063. (2013).

4. Neilson, J., Bulletin RISTRI. 4(3), 183-198 (2013).

5. Morse, S., Mcnamara, N., and Acholo, M., Sustainable livelihood approach : A critical analysis of theory and practice. (2009).

6. Pedersen, M. L., and Petersen, E. K., The Sustianable Livelihood Approach. From a psychological perspective. (2010).

7. www.international coffee organization (2020).

8. Chambers, R., Conway, R., IDS discussion paper. 296, 127 - 130 (1992).

9. Creswell, J. W., P. Clark, V. L., Designing and conducting mixed methods research. (Thousand Oaks. CA, Sage, 2007).

10. Hussein, K. and J. Nelson, IDS Working Paper. 69 (1998). 
11. Vicol. M., Jeffrey, N., Diany, F.S.H., and Peter, C., World Development. 110, 26 -37 (2018).

12. Mulyani, A., Analisis faktor-faktor yang mempengaruhi produktivitas kopi robusta terhadap peningkatan pendapatan ekonomi dalam perspektif ekonomi islam. Universitas Islam Negeri Raden Inten. Lampung. Skripsi. 2019.

13. Sitanggang, A.S., Juliana, B.S., and Rafael, R.W., Regionomic. 2(1), 1 - 9 (2020).

14. Amare, D., and Belaineh, L., Journal of Development and Agricultural Economics. 5(3), $120-128$ (2013).

15. Kebede, M., Haileselassie, A., Gebrehiwot, H., \& Luchia, T., Journal of Agricultural Economics and Development. 3(2), 17-25 (2014).

16. Effendi. Sumberdaya manusia, peluang kerja dan kemiskinan. (Tiara Wacana, Yogyakarta, 1995).

17. Rusastra, I.W., Saliyem, H.P., Supriyati and Saptana, Forum Penelitian Agroekonomi. 22, $37-53$ (2004).

18. Scoones, I., IDS Working Paper. 72 (1998).

19. Neilson, J., World Development. 36(9), 1607 - 1622 (2008).

20. Ellis, F. (2000). Rural livelihoods and diversity in developing countries. (Oxford University Press, Oxford, 2000).

21. Hartatri, D.F.S, J. Neilson, B. Arifin, Y. Fujita. Livelihood strategies of smallholder coffee farmers in South Sulawesi and East Nusa Tenggara (Flores). ASIC. (2010).

22. Derbe, T. ERJSSH. 7, 1 (2010). 